\title{
Yellow-pigmented Strains of Thermus spp. from Icelandic Hot Springs
}

\author{
By R. A. PASK-HUGHES* AND \\ R. A. D. WILLIAMS \\ Department of Biochemistry, The London Hospital Medical College, \\ London $E_{1} 2 A D$
}

(Received 6 April 1977; revised I June 1977)

\begin{abstract}
The DNA of 13 yellow-pigmented strains of the genus Thermus, isolated from hot springs in Iceland, had a mean base composition of 60.5 to $65.1 \mathrm{~mol} \% \mathrm{GC}$. In their growth characteristics and sensitivity to antibiotics, these strains resembled Thermus aquaticus strain YTI. Glutamate, acetate and sucrose, with ammonium ions as a nitrogen source, supported growth. The enzymes of the tricarboxylic acid cycle were present and the glyoxylate cycle was constitutive. The stability of malate dehydrogenase in crude extracts was similar to that of strain YTI.
\end{abstract}

\section{INTRODUCTION}

The description of a new type of extremely thermophilic, aerobic, Gram-negative rod isolated from a hot spring in Yellowstone National Park by Brock \& Freeze (1969) and called Thermus aquaticus has given new impetus to the study of thermophiles, and provided new material for the isolation of thermostable enzymes and for the study of thermostable macromolecules and membranes. Bacteria of this type have been isolated world-wide from neutral or moderately alkaline water between about 50 and $90{ }^{\circ} \mathrm{C}$ (Brock '\& Freeze, 1969; Ramaley \& Hixson, 1970; Oshima \& Imahori, 1971, 1974; Saiki, Kimura \& Arima, 1972; Brock \& Boylen, 1973; Egorova, Pozmogova \& Loginova, 1973; Loginova \& Egorova, 1975; Egorova \& Loginova, 1975; Pask-Hughes \& Williams, 1975). A strain with similar physiological properties to Thermus isolates, but with different pigmentation and morphology and a distinctly alkaline pH optimum, has been described as a representative of a new genus, Thermomicrobium (Jackson, Ramaley \& Meinschein, 1973).

All isolated strains of Thermus grow poorly with single organic compounds as sole carbon source in the presence of mineral salts and ammonium sulphate as a nitrogen source. This paper describes the isolation and properties of a number of yellow-pigmented Thermus strains from hot springs in south-western Iceland, which were studied as part of an investigation of the range of properties of Thermus (Pask-Hughes, 1976) suitable for classification purposes, and to select strains suitable for investigating the problems of thermostability of macromolecules and of thermophily.

* Present address: Microbiological Chemistry Research Laboratory, The University, Newcastle upon Tyne NEI 7 RU. 


\section{METHODS}

Collection of water samples. Water samples were collected in south-western Iceland (Fig. 1) during September 1972. Most of the hot springs were small pools or streams that could be sampled directly by hand. Direct measurements of temperature were usually made in the springs with a thermistor thermometer (Grant Instruments Developments, Barrington, Cambridgeshire) and pH was measured at the appropriate temperature setting with a Pye model 293 portable $\mathrm{pH}$ meter. Where this was not possible, a large volume of water was collected in a $250 \mathrm{ml}$ beaker on the end of a line and the measurements were made as quickly as possible after removal from the spring. Samples of water were passed through Millipore Field Monitors to concentrate suspended matter; the membrane filters were removed and immersed in $20 \mathrm{ml}$ of the original spring water in Sterilin $25 \mathrm{ml}$ tubes for transport to London. Enrichment cultures were set up immediately on arrival in London, that is within Io days of the collection of the first samples.

Isolation and maintenance. Growth medium contained Difco tryptone $\left(3 \mathrm{~g}^{-1}\right)$ and Difco yeast extract $\left(3 \mathrm{~g} \mathrm{l}^{-1}\right)$ with $10 \%(\mathrm{v} / \mathrm{v})$ mineral salts solution (Ramaley \& Hixson, 1970); the pH of the medium was adjusted to 7.6 at room temperature $\left(=7.1\right.$ at 70 to $75^{\circ} \mathrm{C}$ ). Hot spring water $(10 \mathrm{ml})$ was mixed with $10 \mathrm{ml}$ growth medium and incubated for 2 to 5 days at $75^{\circ} \mathrm{C}$ as a shallow layer in a $200 \mathrm{ml}$ bottle lying on its side. Turbid cultures were streaked on plates of solidified growth medium $\left(20 \mathrm{~g} \mathrm{agar}^{-1}\right)$, and these were incubated overnight sealed in polythene bags to prevent drying out. Individual colonies were restreaked repeatedly, and the purified colonies were freeze-dried in brain-heart infusion broth plus serum.

Non-Icelandic Thermus strains. These were Thermus aquaticus Brock \& Freeze 1969, strain YTI (ATCC25 104); strain XI (Ramaley \& Hixson, 1970), kindly donated by Dr R. Ramaley; and strains DI and NH, which have been described previously (Pask-Hughes \& Williams, 1975).

Growth on single substrates. Agar $\left(20 \mathrm{~g}^{-1}\right)$ plates were prepared containing substrate $\left(2 \mathrm{~g}^{1^{-1}}\right)$ together with $\left(\mathrm{NH}_{4}\right)_{2} \mathrm{SO}_{4}\left(0.5 \mathrm{~g}^{-1}\right)$ and $10 \%(\mathrm{v} / \mathrm{v})$ mineral salts solution (Ramaley \& Hixson, 1970). Each strain was streaked on a whole plate for each substrate. Plates were incubated at $70^{\circ} \mathrm{C}$ and examined for growth on the third and fifth days. If growth was sparse and limited to the primary inoculum streak every time it was tested, it was attributed to carry-over of nutrients from the inoculum and scored as negative.

Determination of growth rate. A thermal gradient incubator (Scientific Industries International, Loughborough, Leicestershire) was used with tubes containing $20 \mathrm{ml}$ growth medium shaken at 45 oscillations $\min ^{-1}$. Growth was measured turbidimetrically with an EEL 222 colorimeter.

Antibiotic sensitivity. Plates containing solidified growth medium $\left(20 \mathrm{~g}\right.$ agar $\left.\mathrm{l}^{-1}\right)$ were flooded with a culture of each strain, and air-dried until no free fluid was evident on the agar surface. Oxoid 'Multodiscs' were then applied to the plates and these were incubated in polythene bags at $70^{\circ} \mathrm{C}$. The zone size, from the edge of bacterial growth to the edge of the paper disc, was measured after 3 to 5 days.

Bulk growth of bacteria. Cultures in $500 \mathrm{ml}$ growth medium in 21 Erlenmeyer flasks, fitted with baffles to increase aeration, were incubated at $70^{\circ} \mathrm{C}$ in a Gallenkamp 1 H620 rotary shaking incubator operating at I $50 \mathrm{rev}$. $\mathrm{min}^{-1}$. Bacteria were harvested by centrifuging $(5700 \mathrm{~g})$ for $15 \mathrm{~min}$, washed three times with distilled water and stored at $-20^{\circ} \mathrm{C}$.

Preparation of cell-free extracts. Ice-cold bacterial suspensions were disrupted with an ultrasonic disintegrator, or by pressing in a Biox Press (Nacka, Sweden). Unbroken bacteria and debris were removed by centrifuging at $170000 \mathrm{~g}$ for $2.5 \mathrm{~h}$ and the supernatant was used immediately or stored at $-20^{\circ} \mathrm{C}$.

Spectrophotometry of pigments. Approximately $6 \mathrm{~g}$ wet wt bacteria were dispersed in $10 \mathrm{ml}$ boiling methanol. After $30 \mathrm{~min}$ the mixture was centrifuged and the spectrum of the clear supernatant was recorded between 310 and $510 \mathrm{~nm}$ using a Perkin Elmer 402 spectrophotometer.

Effect of strong acids and bases on pigments. This was tested as described by Jones, Watkins \& Erikson (1973).

Preparation and analysis of DNA. Washed whole bacteria were treated with trypsin $\left(0.2 \mathrm{mg} \mathrm{ml}^{-1}\right.$ in $0.2 \mathrm{M-}$ phosphate buffer $\mathrm{pH} \mathrm{8.0)}$ at $37^{\circ} \mathrm{C}$ for $3 \mathrm{~h}$ and then recovered by centrifuging $(5700 \mathrm{~g}, 15 \mathrm{~min})$. Lysis was carried out with sodium laurylsulphate $\left(20 \mathrm{~g} \mathrm{l}^{-1}\right)$ at $70^{\circ} \mathrm{C}$ for $15 \mathrm{~min}$. DNA was isolated by the method of Marmur (196I). Where DNA was not precipitated in a form that could be spooled on a glass rod, the preparation was left at $4{ }^{\circ} \mathrm{C}$ and the nucleic acid was removed by centrifuging ( $1400 \mathrm{~g}, 10 \mathrm{~min}$ ). Details of the purification and thermal denaturation of DNA were as described by Shah et al. (1976). Both standard saline citrate (Marmur \& Doty, 1962) and 0. I $\times$ standard saline citrate (Schildkraut \& Lifson, 1965) were used. DNA prepared from $T$. aquaticus YTI was used as a standard.

Assay of enzymes of the tricarboxylic acid cycle and glyoxylate cycle. Citrate synthase, aconitase, isocitrate dehydrogenase, 2-oxoglutarate dehydrogenase, fumarase, malate dehydrogenase, isocitrate lyase and malate synthase were assayed spectrophotometrically at $45^{\circ} \mathrm{C}$ in the soluble fraction of cell-free extracts as described by Reeves et al. (I971). Succinate dehydrogenase was measured in the soluble fraction by the method of Jurtshuk et al. (1969). 
Assay and heat inactivation of malate dehydrogenase. This enzyme was assayed by measuring the increase in extinction at $340 \mathrm{~nm}$ due to the reduction of NAD by malate. The assay mixture ( $3 \mathrm{ml}$ ) contained: $25 \mu 1$ cell-free extract; $30 \mu \mathrm{mol}$ malate; I $\mu \mathrm{mol} \mathrm{NAD;} 45 \mu \mathrm{mol}$ EDTA; and $450 \mu \mathrm{mol}$ Tris $/ \mathrm{HCl}, \mathrm{pH} 9.5$. Assays were performed at $45{ }^{\circ} \mathrm{C}$. Heat inactivation was studied by sealing $0.3 \mathrm{ml}$ portions of extract diluted in 50 mm-phosphate buffer pH 7.6 in glass ampoules and totally immersing these in an oil bath at 90,95 or $100{ }^{\circ} \mathrm{C}$. Multiple ampoules were used and one was withdrawn at each time interval, cooled in ice-water, and maintained at $4{ }^{\circ} \mathrm{C}$ until assayed for enzyme activity.

\section{RESULTS AND DISCUSSION}

\section{Isolation of strains}

A total of 35 strains of thermophilic, heterotrophic, Gram-negative bacteria were isolated from the water samples collected from 69 sites in south-western Iceland. Of these, 2 I strains were not perceptibly pigmented and are not discussed here. Thirteen strains, which, like Thermus aquaticus YTI and Thermus thermophilus HB8, are yellow-pigmented, are described in this paper. One further isolate (Williams, 1975), strain B (Table I), differs from these strains, and has been the subject of a more detailed investigation to be reported elsewhere.

Of the major sites sampled (Fig. 1), the very hot waters of Reykjanes provided no isolates. Samples from Mosfell, Krisuvik and Hveragerdi afforded non-pigmented heterotrophs, while thiobacilli were isolated (Le Roux, Wakerley \& Hunt, 1977) from the acid sulphur springs at Hengill, Krisuvik and Hveragerdi. The other sites (Fig. I) together with Reykirvellir ( $5 \mathrm{~km}$ north of Skalholt) gave yellow-pigmented strains (see Table I). The most prolific site was also one of the most readily accessible, being the complex of springs in and around the town of Hveragerdi. The 19 samples taken in this area afforded two pigmented and nine non-pigmented heterotrophs, and five thiobacilli.

All the yellow-pigmented strains, and all but three of the non-pigmented ones, were isolated from sites more alkaline than the enrichment medium ( $\mathrm{pH} 7 \cdot \mathrm{I}$ at $75^{\circ} \mathrm{C}$ ), and 28 of the 35 strains isolated were from water of $\mathrm{pH} 8.1$ to 9.2 . Water at high temperature provides a more hospitable environment for these rapidly growing heterotrophs under moderately alkaline conditions than under neutral or more acid conditions.

The morphology of the strains grown in liquid growth medium was similar to that of T. aquaticus YTI (Brock \& Freeze, 1969). The rods tended to form filaments and in static liquid cultures a pellicle was produced. Colonies on plates of solidified growth medium were paler yellow than those of strain YTI. No growth was observed on common bacteriological media such as horse blood agar and nutrient agar after incubation for 5 days at $70^{\circ} \mathrm{C}$.

\section{Growth on various carbon sources}

The substrates (Table 2) that most commonly supported the growth of the 13 Icelandic strains were glutamate, sucrose and acetate. The inability of all strains to use citrate as the sole carbon source, and of some strains to use malate and succinate, must be due to impermeability as the tricarboxylic acid cycle enzymes are all present (see below). The pattern of utilization of carbon sources resembles that of Thermus strains YTI, XI, NH and DI (Pask-Hughes \& Williams, 1975).

The growth characteristics in tryptone/yeast extract/mineral salts medium seem to be be similar for Japanese (HB8), American (YTI, X1), British (DI, NH) and Icelandic strains (Table 3). The optimum temperature for growth was between 66 and $74{ }^{\circ} \mathrm{C}$, and the upper temperature limit under the conditions used was within the narrower range of 77 to $81{ }^{\circ} \mathrm{C}$. The mean generation time for the Icelandic strains was longer than for the Japanese isolate HB8, but shorter than for the British and American strains.

\section{Antibiotic sensitivity}

There were some problems of interpretation of antibiotic disc tests in view of the conditions that had to be used. Growth was rapid and zones of inhibition were clearly visible 


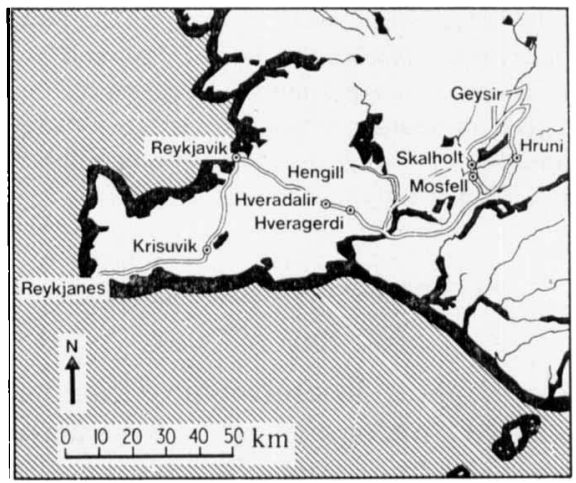

Fig. 1. Map_of south-western Iceland showing the major hot spring sites from which samples were collected.

Table I. Sources, site $p H$ and site temperature of the pigmented strains isolated

\begin{tabular}{|c|c|c|c|}
\hline Strain & Source & Site pH & $\begin{array}{c}\text { Site } \\
\text { temperature } \\
\left({ }^{\circ} \mathrm{C}\right)\end{array}$ \\
\hline D1 & Hveradalir & $7 \cdot 6$ & 69 \\
\hline II & Hveragerdi & $8 \cdot 7$ & 64 \\
\hline $\mathbf{R}$ & Hveragerdi & $7 \cdot 2$ & 73 \\
\hline JI & Skalholt & $8 \cdot 5$ & 80 \\
\hline $\mathbf{K I}$ & Skalholt & $8 \cdot 5$ & 80 \\
\hline $\mathbf{L I}$ & Skalholt & 8.9 & 84 \\
\hline NI & Skalholt & $8 \cdot 4$ & 70 \\
\hline $\mathbf{L}$ & Skalholt & $8 \cdot 2$ & $7 \mathrm{I}$ \\
\hline $\mathbf{K}$ & Skalholt & $8 \cdot \overline{8}$ & 80 \\
\hline $\mathbf{J}$ & Reykirvellir & $8 \cdot 8$ & 75 \\
\hline $\mathbf{H}$ & Geysir & $8 \cdot 2$ & 72 \\
\hline G & Geysir & $8 \cdot 6$ & 75 \\
\hline $\mathbf{F}$ & Geysir & $8 \cdot 6$ & 79 \\
\hline $\mathbf{R}$ & Hruni & $8 \cdot 9$ & 82 \\
\hline \multicolumn{4}{|c|}{ Isolates of other workers } \\
\hline HB8 & $\begin{array}{l}\text { Mine hot springs } \\
\text { (Japan) (Oshima } \\
\text { \& Imahori, 1974) }\end{array}$ & $6 \cdot 3$ & 80 \\
\hline YTI & $\begin{array}{l}\text { Yellowstone } \\
\text { National Park } \\
\text { (U.S.A.) (Brock \& } \\
\text { Freeze, 1969) }\end{array}$ & 8.9 & $7 x \cdot 5$ \\
\hline
\end{tabular}

after overnight incubation. The long incubation period was employed solely to ensure maximum growth and pigmentation of cells for photography. As the bacteria were sensitive to most of the antibiotics, the inhibitors are apparently stable at $70^{\circ} \mathrm{C}$ during the growth period. When the sensitivity discs were incubated at $70^{\circ} \mathrm{C}$ in a moist atmosphere for 4 to $48 \mathrm{~h}$ and then tested against Staphylococcus aureus (NCTC657I) and Escherichia coli (NCTCI0418), the activities of neomycin, novobiocin, fusidate, chloramphenicol, erythromycin, sulphafurazole, streptomycin and colistin were unchanged, that of tetracycline was slightly decreased within $48 \mathrm{~h}$, and those of kanamycin, penicillin, ampicillin and cloxacillin were decreased giving zones of inhibition half the size of those with untreated discs after 28 to $48 \mathrm{~h}$ at $70^{\circ} \mathrm{C}$. Methicillin was the most sensitive to heat and became ineffective after 2I h at $70^{\circ} \mathrm{C}$. As methicillin inhibited the thermophiles in spite of its thermolability, the general validity of the antibiotic tests at high temperatures is confirmed.

The pattern of antibiotic inhibition of the Icelandic bacteria (Table 4) was similar to that 
Table 2. Growth on agar plates containing single substrates

\begin{tabular}{|c|c|c|c|c|c|c|c|c|c|c|c|c|c|}
\hline \multirow{2}{*}{$\begin{array}{l}\text { Substrate } \\
\left(2 \mathrm{~g} \mathrm{I}^{-1}\right)\end{array}$} & \multicolumn{13}{|c|}{ Strain } \\
\hline & D1 & $\mathbf{F}$ & G & H & II & $\mathbf{J}$ & JI & K & KI & $\mathbf{L}$ & LI & NI & $\mathbf{R}$ \\
\hline Sucrose & + & + & + & ++ & \pm & + & - & + & - & ++ & - & + & - \\
\hline Starch & + & \pm & - & ++ & - & - & - & - & - & - & - & + & - \\
\hline Succinate & - & $=$ & - & \pm & - & - & - & \pm & - & - & - & - & - \\
\hline Malate & \pm & - & - & ++ & + & - & \pm & - & - & + & - & - & - \\
\hline Formate & \pm & - & - & ++ & - & - & $=$ & - & - & - & - & - & - \\
\hline Acetate & - & + & + & ++ & + & + & \pm & ++ & + & ++ & \pm & \pm & - \\
\hline Alanine & - & - & - & - & - & - & $\overline{-}$ & - & - & - & $=$ & + & - \\
\hline Glutamate & ++ & ++ & \pm & \pm & - & - & \pm & ++ & + & ++ & \pm & + & - \\
\hline Mannitol & \pm & \pm & $=$ & + & - & - & $=$ & - & - & - & - & - & \pm \\
\hline Glycerol & $=$ & $=$ & \pm & - & - & - & - & + & - & - & - & \pm & $\overline{-}$ \\
\hline
\end{tabular}

,++ Good growth; + , distinct growth; \pm , growth slight and irregular and limited to the primary inoculum streak; -, no growth.

No growth was detected on glucose, fructose, arabinose, xylose, citrate or glycine.

Table 3. Effect of temperature on growth rate in tryptone/yeast extract/mineral salts medium

Mean generation times were determined at the optimum growth temperature and at intervals from the optimum temperature for each strain. The upper temperature limit at which no apparent growth occurred was also determined.

\begin{tabular}{|c|c|c|c|c|c|c|}
\hline \multirow[b]{2}{*}{ Strain } & \multirow{2}{*}{$\begin{array}{l}\text { Optimum } \\
\text { growth } \\
\text { temperature } \\
\left({ }^{\circ} \mathrm{C}\right)\end{array}$} & \multirow{2}{*}{$\begin{array}{c}\text { Upper } \\
\text { temperature } \\
\text { limit } \\
\left({ }^{\circ} \mathrm{C}\right)\end{array}$} & \multicolumn{4}{|c|}{ Mean generation time (min) } \\
\hline & & & $\begin{array}{l}\text { Optimum } \\
\text { temperature }\end{array}$ & $\begin{array}{l}\text { Optimum } \\
+\quad 5^{\circ} \mathrm{C}\end{array}$ & $\begin{array}{c}\text { Optimum } \\
-10{ }^{\circ} \mathrm{C}\end{array}$ & $\begin{array}{l}\text { Optimum } \\
-15{ }^{\circ} \mathrm{C}\end{array}$ \\
\hline \multicolumn{7}{|c|}{ Non-Icelandic strains } \\
\hline HB8 & $71 \cdot 8-74 \cdot 0$ & $80 \cdot 9$ & 3I & 61 & 59 & 80 \\
\hline YTI & $70 \cdot 0-71 \cdot 0$ & $80 \cdot 8$ & 78 & 114 & 93 & I 49 \\
\hline $\mathbf{X I}$ & $70 \cdot 0-71 \cdot 0$ & $77 \cdot 6$ & 58 & 102 & 81 & 130 \\
\hline DI & $68 \cdot 2-71 \cdot 7$ & $77 \cdot 8$ & 66 & 110 & I IO & 208 \\
\hline NH & $67 \cdot 2-72 \cdot 2$ & $78 \cdot 6$ & 67 & 73 & 92 & 117 \\
\hline \multicolumn{7}{|c|}{ Icelandic strains } \\
\hline G & $66 \cdot 0-68 \cdot 0$ & $81 \cdot 0$ & 42 & 49 & 66 & 95 \\
\hline II & $68 \cdot 0-71 \cdot 0$ & ND & 50 & 57 & 70 & 188 \\
\hline $\mathbf{J}$ & $68 \cdot 0-72 \cdot 9$ & $79 \cdot 8$ & 48 & 54 & 70 & 117 \\
\hline LI & $68 \cdot 0-72 \cdot 8$ & $78 \cdot 8$ & 46 & 68 & 60 & 69 \\
\hline NI & $69 \cdot 0-70 \cdot 0$ & $79 \cdot 8$ & 48 & 67 & 87 & NG \\
\hline $\mathbf{R}$ & $70 \cdot 7-74 \cdot 5$ & ND & 48 & 80 & 62 & 85 \\
\hline
\end{tabular}

ND, Not determined; NG, no growth detected.

for Thermus strains YTI, XI, NH and DI. A high sensitivity to the penicillins, streptomycin, erythromycin and chloramphenicol was observed. Sensitivity to kanamycin, neomycin, novobiocin and tetracycline varied but was usually extensive. Colistin usually gave small zones of inhibition comparable with results for other Gram-negative bacteria. The inhibition by sulphafurazole on the growth medium, which contains tryptone and yeast extract, may be due to the high concentration of sulphafurazole employed and to the necessity of growing these bacteria on a relatively dilute medium which may, in these circumstances, contribute an inadequate supply of nutrients such as purines.

\section{Pigment}

The Icelandic isolates are not as deeply pigmented as the bright yellow colonies of $T$. aquaticus YTI but methanol extracts of three strains (K, F and $\mathrm{R}$ ) had similar spectra to both YTI and HB8 (type I spectrum, Table 5). In another seven Icelandic strains tested, the major 


\section{Table 4. Sensitivity to antibiotics}

\begin{tabular}{|c|c|c|c|c|c|c|c|c|c|c|c|c|c|c|}
\hline \multirow[b]{2}{*}{ Antibiotic } & \multirow{2}{*}{$\begin{array}{c}\text { Dose } \\
(\mu \mathrm{g})\end{array}$} & \multicolumn{13}{|c|}{ Strain } \\
\hline & & D1 & $\mathbf{F}$ & G & $\mathbf{H}$ & II & $\mathbf{J}$ & JI & $\mathbf{K}$ & $\mathbf{K I}$ & $\mathbf{L}$ & LI & NI & $\mathbf{R}$ \\
\hline Fusidate & 10 & - & - & - & $2+$ & - & - & - & - & - & - & - & - & - \\
\hline Colistin & 50 & + & + & + & $2+$ & + & + & + & + & + & + & + & + & + \\
\hline Kanamycin & 5 & $2+$ & $2+$ & $2+$ & $3+$ & $2+$ & $2+$ & $2+$ & + & $2+$ & $2+$ & $2+$ & $2+$ & $2+$ \\
\hline Neomycin & 10 & $2+$ & $3+$ & $3+$ & $3+$ & $3+$ & $2+$ & $3+$ & $2+$ & $3+$ & $3+$ & $3+$ & + & $3+$ \\
\hline Novobiocin & 5 & + & $2+$ & $3+$ & $3+$ & $2+$ & $2+$ & $2+$ & $2+$ & $3+$ & $2+$ & + & $3+$ & $2+$ \\
\hline Tetracycline & 50 & $3+$ & $3+$ & $2+$ & + & $2+$ & $2+$ & $3+$ & $2+$ & $2+$ & $3+$ & $2+$ & $2+$ & $3+$ \\
\hline Sulphafurazole & 500 & $3+$ & $3+$ & - & $3+$ & $3+$ & + & + & $3+$ & - & $3+$ & + & - & + \\
\hline
\end{tabular}

- , No zone of inhibition; + , zone of inhibition less than $6 \mathrm{~mm}$ from edge of disc; $2+$, zone of inhibition greater than $6 \mathrm{~mm}$ but less than $12 \mathrm{~mm}$ from edge of disc; $3+$, zone of inhibition greater than $12 \mathrm{~mm}$ from edge of disc.

$3+$ inhibition was obtained with $5 \mu \mathrm{g}$ cloxacillin, $2 \mu \mathrm{g}$ ampicillin, $10 \mu \mathrm{g}$ methicillin, 5 units penicillin $\mathrm{G}$, $25 \mu \mathrm{g}$ streptomycin, $50 \mu \mathrm{g}$ erythromycin and $50 \mu \mathrm{g}$ chloramphenicol.

Table 5. Spectral characteristics of methanol extracts of whole cells

Strain

Type I spectrum

YTI

$\mathbf{K}$

$\mathbf{F}$

$\mathbf{R}$

YTi†

HB8‡

Type 2 spectrum

D1

H

JI

K I

L.

LI

NI
Wavelength $(\mathrm{nm})$ of major features* in spectrum

$\begin{array}{lll} & & \\ 400(\mathrm{~S}) 428(\mathrm{~S}) & 451(\mathrm{P}) & 475(\mathrm{~S}) \\ 409(\mathrm{~S}) 425(\mathrm{~S}) & 447(\mathrm{P}) & 474(\mathrm{~S}) \\ 409(\mathrm{~S}) 433(\mathrm{~S}) & 458(\mathrm{P}) & 474(\mathrm{~S}) \\ 425(\mathrm{~S}) & 447(\mathrm{P}) & 474(\mathrm{~S}) \\ 428 & 452 & 480 \\ 430(\mathrm{~S}) & 453(\mathrm{P}) & 473(\mathrm{~S}) \\ & & \\ 408(\mathrm{P}) & 458(\mathrm{~S}) & - \\ 407(\mathrm{P}) & 450(\mathrm{~S}) & 490(\mathrm{~S}) \\ 402(\mathrm{P}) & 452(\mathrm{~S}) & 482(\mathrm{~S}) \\ 407(\mathrm{P}) & 452(\mathrm{~S}) & 478(\mathrm{~S}) \\ 407(\mathrm{P}) & 455(\mathrm{~S}) & 494(\mathrm{~S}) \\ 405(\mathrm{P}) & 450(\mathrm{~S}) & - \\ 405(\mathrm{P}) & - & -\end{array}$

* S, Shoulder in spectrum; P, Peak in spectrum.

$\dagger$ From Heinen et al. (1971), for acetone-extracted pigment.

¥ From Oshima \& Imahori (1971), for acetone-extracted pigment.

absorbance of methanol extracts was at a shorter wavelength (type 2 spectrum, Table 5). The development of colours shown by some mesophilic, Gram-positive, yellow-pigmented rods (Jones et al., I973) was not detected when colonies of T. aquaticus YTI, T. thermophilus $\mathrm{HB} 8$ and the Icelandic strains were treated with strong acids or bases.

\section{Base composition of DNA}

The DNA base composition of the Icelandic strains ranged from 60.5 to $65.1 \mathrm{~mol} \% \mathrm{GC}$ (Table 6). Our estimate of $\%$ GC for $T$. aquaticus YTI, by thermal denaturation, was $2 \cdot 3 \%$ lower than the value obtained by Brock \& Freeze (1969) by buoyant density centrifugation. Such differences between laboratories are common, particularly when different techniques are employed. Thus most of the strains so far tested, including the three Y-VII strains (Brock \& Freeze, I969), have similar base compositions of about 62 to $65 \mathrm{~mol} \% \mathrm{GC}$.

\section{Enzymes of the tricarboxylic acid and glyoxylate cycles}

All the enzymes of the tricarboxylic acid cycle were detected in cell-free extracts of Icelandic isolates and of T. aquaticus YTI (Table 7). Succinate dehydrogenase was not measured quantitatively as assays prepared with relatively large volumes of cell-free extract showed 
Table 6. Mean base composition of DNA determined by thermal denaturation

Results show the mean mol \% GC, with individual determinations in parentheses. Results from other sources were determined by buoyant density centrifugation.

\begin{tabular}{|c|c|c|c|}
\hline Strain & Mean mol \% GC & Strain & Mean mol \% GC \\
\hline $\begin{array}{l}\text { D1 } \\
\text { F }\end{array}$ & $\begin{array}{l}60 \cdot 5(60 \cdot 5) \\
62 \cdot 9(63 \cdot 3,62 \cdot 5)\end{array}$ & $\begin{array}{l}\text { Thermus thermophilus HB8 } \\
\text { Thermus aquaticus }\end{array}$ & $68 \cdot 3^{*}$ \\
\hline G & $63 \cdot 3(63 \cdot 4,63 \cdot 2)$ & YTI & $67.4 \dagger$ \\
\hline $\mathbf{H}$ & $64 \cdot 7(65 \cdot 1,64 \cdot 7)$ & Y-VII-5ID & $65.4 \dagger$ \\
\hline II & $62 \cdot 0(62 \cdot 0,62 \cdot 0)$ & Y-VII-5614C & $65.4^{\dagger}$ \\
\hline J & $65 \cdot 0(65 \cdot 1,64 \cdot 9)$ & Y-VII-563A & $65.4 \dagger$ \\
\hline JI & $64 \cdot 2(64.4,63.9)$ & Thermus sp. xI & $64-65 \ddagger$ \\
\hline $\mathbf{K}$ & $64 \cdot 7(65 \cdot 1,64 \cdot 7,64 \cdot 4)$ & Thermomicrobium roseum & $64 \cdot 3 \ddagger$ \\
\hline KI & $63 \cdot 7(63.9,63 \cdot 4)$ & & \\
\hline LI & $65 \cdot 1(65 \cdot 4,64 \cdot 9,65 \cdot 9)$ & & \\
\hline NI & $6 I \cdot I(6 I \cdot 2,6 I \cdot 0)$ & & \\
\hline $\mathbf{R}$ & $64 \cdot 5(64 \cdot 7,64 \cdot 2)$ & & \\
\hline YTI (type strain) & $\begin{array}{l}65 \cdot 1(64 \cdot 9,64 \cdot 7,65 \cdot 9 \\
65 \cdot 4,64 \cdot 6)\end{array}$ & & \\
\hline
\end{tabular}

Table 7. Activity of enzymes of the tricarboxylic acid cycle and glyoxylate cycle in cell-free extracts of Thermus isolates

\begin{tabular}{|c|c|c|c|c|c|}
\hline \multirow[b]{2}{*}{ Enzyme } & \multicolumn{5}{|c|}{$\begin{array}{c}\text { Specific activity at } 45{ }^{\circ} \mathrm{C} \\
{\left[\mathrm{nmol}(\mathrm{mg} \text { protein })^{-1} \mathrm{~min}^{-1}\right]}\end{array}$} \\
\hline & $\mathbf{R}$ & $\mathbf{L I}$ & sI & $\mathbf{K}$ & YTI \\
\hline Citrate synthase & 176 & 569 & 146 & 162 & 452 \\
\hline Aconitase & $21 \cdot I$ & $14 \cdot 6$ & $16 \cdot 1$ & $5 \cdot 5$ & 16.6 \\
\hline Isocitrate dehydrogenase & 369 & 622 & 260 & 313 & 519 \\
\hline 2-Oxoglutarate dehydrogenase & 210 & 510 & ND & ND & 197 \\
\hline Succinate dehydrogenase & + & + & + & + & 106 \\
\hline Fumarase & $4 \cdot 1$ & $4 \cdot 8$ & 3.9 & $5 \cdot 3$ & 3.6 \\
\hline Malate dehydrogenase & 6913 & 6223 & 522 & 632 & 8590 \\
\hline Malate synthase & 29.4 & II 6 & $53 \cdot 8$ & 55.4 & 15.0 \\
\hline Isocitrate lyase & 10.6 & $21 \cdot 8$ & $7 \cdot 2$ & $10 \cdot 1$ & 34.0 \\
\hline
\end{tabular}

ND, Not determined; +, enzyme detected qualitatively.

very rapid reduction of dichlorophenolindophenol after several minutes lag, while with small quantities of extract lag periods were very long before any reaction took place. Malate synthase and isocitrate lyase appeared to be constitutive enzymes in all strains tested; thus the inability of strain $\mathbf{R}$ to grow on acetate as the sole carbon source, and the limited capacity of LI, JI and NI to utilize acetate, may be due to lack of a transport system for acetate although with strain $R$, which is unable to grow well on any single organic compound tested, this may be a general deficiency.

\section{Thermal stability of malate dehydrogenase}

The thermal stability of malate dehydrogenase in cell-free extracts of six Icelandic strains was similar to that of the same enzyme from T. aquaticus YTI (Brock \& Freeze, 1969) and from the hot tap-water strain NH (Pask-Hughes \& Williams, 1975) under the conditions tested. The decay of enzymic activity with time was sigmoid, showing an initial lag period during which little or no inactivation took place. The half-life was taken from the time of first exposure to high temperature, not from the onset of rapid inactivation. Plots of the logarithm of the half-life versus the temperature of exposure were linear (Fig. 2) and converged as the thermal stress increased. Of those strains tested, only $\mathrm{JI}$ and B had malate dehydrogenase that was more stable than that of strain YTI from which the enzyme has been purified (Biffen \& Williams, 1976). 


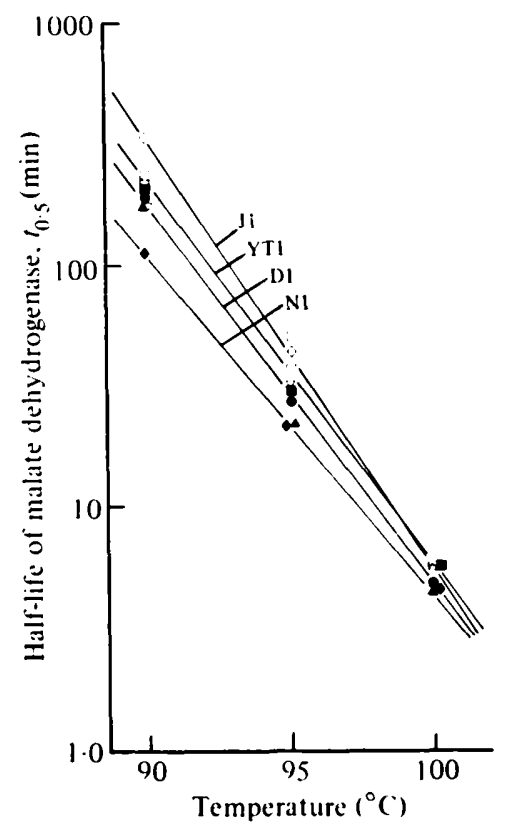

Fig. 2. Effect of temperature on the half-life of malate dehydrogenase in cell-free extracts of

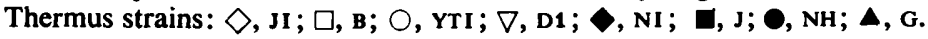

Work on the thermal stability and properties of malate dehydrogenase was supported by the Science' Research Council. Funds for purchase of the thermal gradient incubator were provided by The Royal Society. The study visit to Iceland was supported by the European Scientific Exchange Programme of The Royal Society.

\section{REFERENCES}

Biffen, J. H. F. \& Williams, R. A. D. (I976). Purification and properties of malate dehydrogenase from Thermus aquaticus. In Symposium on Enzymes and Proteins from Thermophilic Microorganisms, Zurich, 1975, pp. 157-167. Basel: Birkhauser-Verlag.

Brock, T. D. \& Boylen, K. L. (1973). Presence of thermophilic bacteria in laundry and domestic hot water heaters. Applied Microbiology 25, 72-76.

Brock, T. D. \& FreEze, H. (1969), Thermus aquaticus gen.n. and sp.n., a non-sporulating extreme thermophile. Journal of Bacteriology 98, 289-297.

Egorova, L. A. \& Loginova, L. G. (1975). Distribution of extreme thermophilic nonsporogenous bacteria in Tadshikistan hot springs. Mikrobiologiya 44, 938-942.

Egorova, L. A., Pozmogova, I. N. \& Loginova, L. G. (1973). Extreme thermophilic bacteria from Kamchatka hot springs. Doklady Akademii nauk SSSR 212, 747-750.

Heinen, U. J., KLein, G., Klein, H. P. \& Heinen, W. (I97I). Comparative studies on the nature and distribution of pigments from two thermophilic bacteria. Archiv für Mikrobiologie 76, 18-27.

Jackson, T. J., Ramaley, R. F. \& Meinschein, W. G. (1973). Thermomicrobium, a new genus of extremely the rmophilicbacteria. International Journal of Systematic Bacteriology 23, 28-36.

Jones, D., Watkins, J. \& ERIkson, S. K. (1973). Taxonomically significant colour changes in Brevibacterium linens probably associated with a carotenoid-like pigment. Journal of General Microbiology 77, 145-150.

Jurtshuk, P., May, A. K., Pope, L. M. \& Aston, P. R. (1969). Comparative studies on succinate and terminal oxidase activity in microbial electron transport systems. Canadian Journal of Microbiology 15, 797-807.

Le Roux, N. W., Wakerley, D. S. \& Hunt, S. D. (1977). Thermophilic Thiobacillus-type bacteria from Icelandic thermal areas. Journal of General Microbiology 100, 197-201.

Loginova, L. G. \& Egorova, L. A. (1975). An obligately thermophilic bacterium Thermus ruber from hot springs in Kamchatka. Mikrobiologiya 44, 66I-665.

MARMur, J. (196I). A procedure for the isolation of deoxyribonucleic acid from microorganisms. Journal of Molecular Biology 3, 208-2 18.

MARMUR, J. \& DOTY, P. (I962). Determination of the base composition of deoxyribunucleic acid 
from its thermal denaturation temperature. Journal of Molecular Biology 5, 109-1 18.

Oshima, T. (1972). Studies on an extreme thermophile, Flavobacterium thermophilum нв8. In Molecular Evolution: Prebiological and Biological, pp. 399-423. Edited by D. L. Rohlfing and A. L. Oparin. New York: Plenum Press.

OSHIMA, T. \& IMAHORI, K. (1971). Isolation of an extreme thermophile and thermostability of its transfer ribonucleic acid and ribosomes. Journal of General and Applied Microbiology 17, 513-517.

Oshima, T. \& IMAHORI, K. (1974). Description of Thermus thermophilus (Yoshida and Oshima) comb. nov. A non-sporulating thermophilic bacterium from a Japanese thermal spa. International Journal of Systematic Bacteriology 24, I02-1I 2.

Pask-Hughes, R. A. (1976). Properties of Gramnegative extremely thermophilic bacteria and the investigation of their cell envelopes. Ph.D. thesis, University of London.

Pask-Hughes, R. A. \& Williams, R. A. D. (1975). Extremely thermophilic Gram-negative bacteria from hot tap water. Journal of General Microbiology 88, $32 \mathrm{I}-328$.
Ramaley, R. F. \& Hixson, J. (1970). Isolation of a non-pigmented, thermophilic bacterium similar to Thermus aquaticus. Journal of Bacteriology 103, 527-528.

Reeves, H. C., Rabin, R., Wegener, W. S. \& Ajl, S. J. (197 I). Assays of enzymes of the tricarboxylic acid and glyoxylate cycles. Methods in Microbiology 6A, 425-462.

Shah, H. N., Williams, R. A. D., Bowden, G. H. \& HaRdie, J. M. (1976). Comparison of the biochemical properties of Bacteroides melaninogenicus from human dental plaque and other sites. Journal of Applied Bacteriology 4r, 473-492.

SAIKI, T., KimurA, R. \& ARIMA, K. (1972). Isolation and characterisation of extremely thermophilic bacteria from hot springs. Agricultural and Biological Chemistry 36, 2357-2366.

Schildkraut, C. \& Lifson, S. (1965). Dependence of the melting temperatures of DNA on salt concentration. Biopolymers 3, 195-208.

WILliams, R. A. D. (I975). Caldoactive and thermophilic bacteria and their thermostable proteins. Science Progress, Oxford 62, 373-393. 